Article

\title{
A Cytotoxic and Anti-inflammatory Campesterol Derivative from Genetically Transformed Hairy Roots of Lopezia racemosa Cav. (Onagraceae)
}

\author{
Norma Elizabeth Moreno-Anzúrez ${ }^{1}$, Silvia Marquina ${ }^{2, *}$, Laura Alvarez ${ }^{2}$, Alejandro Zamilpa ${ }^{3}$, \\ Patricia Castillo-España ${ }^{1}$, Irene Perea-Arango ${ }^{1}$, Pilar Nicasio Torres ${ }^{3}$, Maribel Herrera-Ruiz ${ }^{3}$, \\ Edgar Rolando Díaz García ${ }^{3}$, Jaime Tortoriello García ${ }^{3}$ and Jesús Arellano-García ${ }^{1, *}$ \\ 1 Centro Investigación en Biotecnología, Universidad Autónoma del Estado de Morelos, \\ Av. Universidad 1001 Col, Chamilpa C.P. 62209, Cuernavaca, Morelos, Mexico; \\ norma.moreno@uaem.mx (N.E.M.-A.); castillo@uaem.mx (P.C.-E.); iperea@uaem.mx (I.P.-A.) \\ 2 Centro de Investigaciones Químicas-IICBA, Universidad Autónoma del Estado de Morelos, \\ Av. Universidad 1001 Col, Chamilpa C.P. 62209, Cuernavaca, Morelos, Mexico; lalvarez@uaem.mx \\ 3 Centro de Investigación Biomédica del Sur (IMSS), Argentina No. 1, Xochitepec Centro C.P. 62790, \\ Morelos, Mexico; azamilpa_2000@yahoo.com.mx (A.Z.); pisaliva@yahoo.com.mx (P.N.T.); \\ edanae10@yahoo.com.mx (M.H.-R.); edgarrdg@hotmail.com (E.R.D.G.); \\ jaime.tortoriello@imss.gob.mx (J.T.G.) \\ * Correspondence: smarquina21@hotmail.com (S.M.); jesus.arellano@uaem.mx (J.A.-G.); \\ Tel.: +52-777-329-7997 (S.M.); +52-777-329-7057 (J.A.-G.)
}

Academic Editor: Derek J. McPhee

Received: 12 November 2016; Accepted: 5 January 2017; Published: 12 January 2017

\begin{abstract}
The genetically transformed hairy root line LRT 7.31 obtained by infecting leaf explants of Lopezia racemosa Cav with the Agrobacterium rhizogenes strain ATCC15834/pTDT, was evaluated to identify the anti-inflammatory and cytotoxic compounds reported previously for the wild plant. After several subcultures of the LRT 7.31 line, the bio-guided fractionation of the dichloromethane-methanol (1:1) extract obtained from dry biomass afforded a fraction that showed important in vivo anti-inflammatory, and in vitro cytotoxic activities. Chemical separation of the active fraction allowed us to identify the triterpenes ursolic (1) and oleanolic (2) acids, and (23R)-2 $\alpha$, $3 \beta, 23,28$-tetrahydroxy-14,15-dehydrocampesterol (3) as the anti-inflammatory principles of the active fraction. A new molecule 3 was characterized by spectroscopic analysis of its tetraacetate derivative 3a. This compound was not described in previous reports of callus cultures, in vitro germinated seedlings and wild plant extracts of whole L. racemosa plants. The anti-inflammatory and cytotoxic activities displayed by the fraction are associated to the presence of compounds 1-3. The present study reports the obtaining of the transformed hairy roots, the bioguided isolation of the new molecule 3 , and its structure characterization.
\end{abstract}

Keywords: genetic transformation; Lopezia racemosa; Agrobacterium rhizogenes; hairy roots; cytotoxic; anti-inflammatory

\section{Introduction}

Plants usually produce or accumulate very low quantities of metabolites of interest and large quantities of plant material are necessary to obtain an active substance, so in this sense hairy roots represent an alternative to overcome this problem and to produce higher amounts of secondary metabolites, or recently known specialized metabolites [1]. In recent years, several workers have reported the use of hairy root cultures for the production of secondary metabolites such as silymarin, a mixture of flavonolignans with hepatoprotective properties from hairy root cultures of Sylibum marianum [2], 
methyllycaconitine, a potential drug for the treatment of Alzheimer's disease from mutagenesized hairy root cultures of Solidago memoralis [3], podophyllotoxin and 6-methoxy-podophyllotoxin from hairy roots of Linum mucronatum [4], and also the production of primary metabolites such as polyunsaturated fatty acids from hairy root cultures of Echium acanthocarpum [5]. Several additional strategies have also been implemented to enhance the metabolite production of hairy roots which include yield improvements as well as modification of the metabolism of hairy root cultures. Weathers et al. [6] reported that the addition of plant growth regulators could improve the growth and artemisinin production of hairy root cultures of Artemisia annua. Moreover, elicitors of secondary metabolism have long been used to increase the production of cell suspension and hairy root cultures [7].

Lopezia racemosa Cav. (Onagraceae) (Figure 1c), commonly known as punch herb or cancer herb, has long been used in traditional Mexican medicine to heal inflammatory diseases [8]. It was previously demonstrated that some fractioned extracts of this plant possess antimicrobial, antiparasitic, anti-inflammatory and cytotoxic activities [9]. Afterwards, bioassay-guided fractionation afforded the acylglucosylsterols 6-O-palmitoyl-3-O- $\beta$-D-glucopyranosylcampesterol (I) and 6-O-palmitoyl-3$O$ - $\beta$-D-glucopyranosyl- $\beta$-sitosterol (II), which were found to have anti-inflammatory and cytotoxic activities, respectively. Both were isolated and purified from wild plants, in vitro germinated seedlings, and callus cultures of L. racemosa [10]. Compound II was also isolated from Ficus carica [11]. Callus cultures produced lower or similar amounts of active metabolites compared to those found in the wild plant. In this study with the aim to increase the production of the anti-inflammatory and cytotoxic metabolites, transformed hairy roots lines from L. racemosa leaf explants were produced using A. rhizogenes strain ATCC 15834/pTDT. Selected hairy root line (LRT 7.31) showed in vivo anti-inflammatory activity and in vitro cytotoxic activity, but the phytochemical study outlined revealed that the active compounds I and II, previously described in the wild plant, in vitro germinated seedlings and callus cultures were not found, instead, a new sterol identified as (23R)-2 $\alpha, 3 \beta, 23,28$-tetrahydroxy-14,15-dehydrocampesterol (3) was isolated and purified.
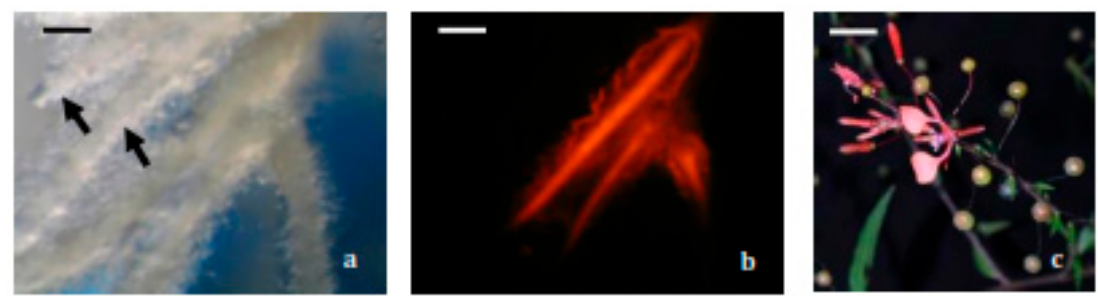

Figure 1. Photomicrographs $(5 \times)$ of genetically transformed hairy roots of Lopezia racemosa. The same field observed under epifluorescence microscopy: (a) observed under white light; (b) observed under green light $(550 \mathrm{~nm})$. On the left upper part (arrows) non-fluorescent hairy roots derived from the same explant can be observed; (c) Lopezia racemosa wild plant. Scale bars: a and b: $1.0 \mathrm{~mm}$; : $1.0 \mathrm{~cm}$.

The present study describes the genetic transformation process and selection of hairy root lines, as well as the extraction, fractionation, and purification of the new sterol 3, derived from the hairy root line LRT 7.31. Evaluation of the anti-inflammatory and cytotoxic activities is also discussed.

\section{Results and Discussion}

\subsection{Hairy Roots Obtaining and Selection}

From 113 infected leaf explants, only 43 generated hairy roots, giving a transformation frequency (TF) of $38 \%$. The TF is usually reported as the percentage of explants that show a positive response relative to the total number of infected explants. The TF can vary widely with the plant species and Agrobacterium strain used, as well as with the conditions employed to carry out the infection and with the type of explants used, among others factors. In a recent report, Ashraf et al. [12] used the A. rhizogenes strain 15834 to infect leaf explants of Persicaria minor and obtained a TF of $8.8 \%$ using 
acetosyringone as an activator of vir genes. Wahyuni et al. [13], using the same Agrobacterium strain, obtained a TF of $70 \%$ in leaf explants of Justicia gendarussa without addition of vir gene inducers. Our results fall between the values mentioned above (38\%).

After three weeks of bacteria elimination more than 300 individualized hairy roots derived from all the responsive explants were transferred to hairy root selection medium and 22 actively growing hairy roots were obtained, being LRT 7.31 one of the selected lines. The growth index (GI) of this line was $78.14 \pm 3.14$, resulting higher than other hairy root lines. It is important to note that this low number of transformed hairy roots could be explained by the fact that not all the roots emerging from an explant are transformed (Figure $1 \mathrm{a}, \mathrm{b}$ ).

The genetic transformation of selected hairy root lines such as LRT 7.31, LRT 6.14, LRT 6.4, LRT 3.1 and LRT 17.6 was confirmed by PCR analysis (Figure 2). We observed that among the tested root lines, only line LRT 6.14 did not amplify the expected fragment of $490 \mathrm{bp}$, although it is actively growing. It is necessary to test amplification for other $r o l$ genes, such as rolB or rolA, in order to explain the active growth of this hairy root line.
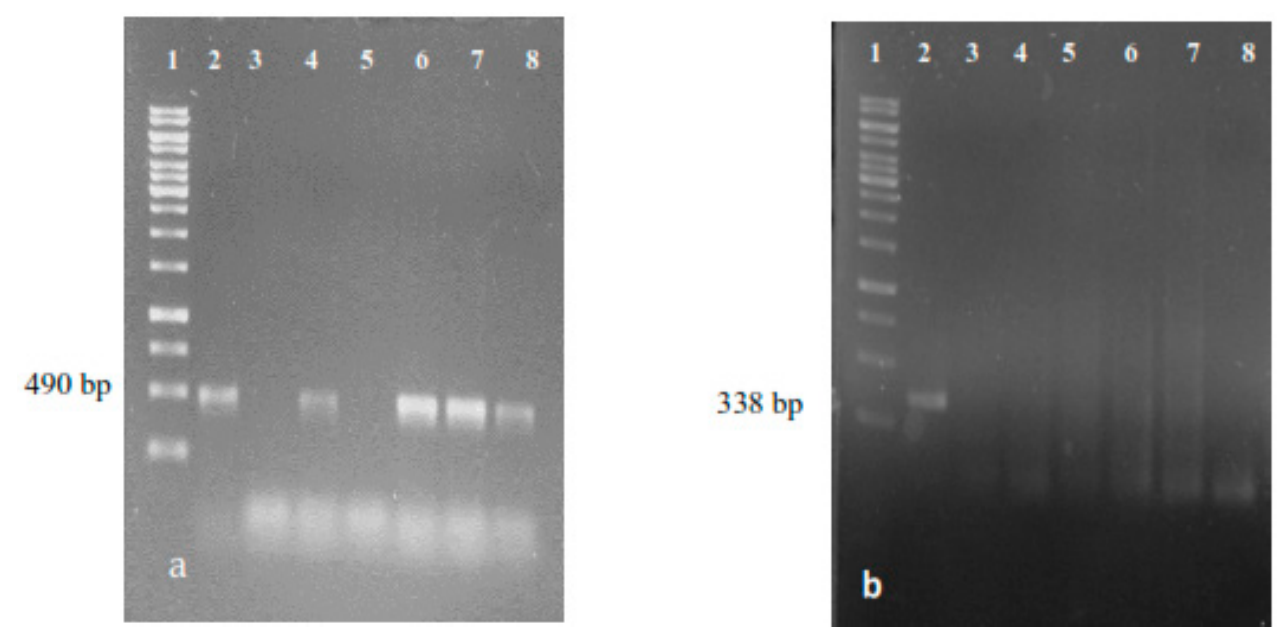

Figure 2. PCR products of transformed hairy roots derived from L. racemosa. (a) Amplifying a $490 \mathrm{bp}$ fragment of the rolC gen of $A$. rhizogenes ATCC 15834. Lane 1: $1 \mathrm{~Kb}$ DNA marker; lane 2: Positive control, PCR product from total DNA of $A$. rhizogenes ATCC 15834; Lane 3: Negative control, PCR product from total DNA of non-transformed roots of L. racemosa; lanes 4-8: PCR products from total DNA of 5 hairy root lines derived from L. racemosa, (lines 7.31, 6.14, 6.4, 3.1 and 17.6, respectively); (b) Amplifying a $338 \mathrm{bp}$ fragment of the virD gen of $A$. rhizogenes ATCC 15834. Lane 1: $1 \mathrm{~Kb}$ DNA marker; lane 2: Positive control, PCR product from total DNA of A. rhizogenes ATCC 15834; lane 3: Negative control, PCR product from total DNA of non-transformed roots of L. racemosa; lanes 4-8: PCR products from total DNA of 5 hairy root lines derived from L. racemosa.

It had been proposed that crown galls induced by $A$. tumefaciens are chimerical tissues, since the auxin and cytokinin produced by transformed plant cells containing and expressing the genes transferred through the T-DNA modify the growth pattern of untransformed cells beside them, while roots induced by $A$. rhizogenes appear to be composed only of transformed cells [14]. However, we found that in our case most of the roots emerging from the responsive explants did not continue growing when they were cut off from the original explant and individually transferred to a new culture medium without plant growth regulators. We therefore considered each individual hairy root as a product of different transformation events, since we observed at least three different root phenotypes: red fluorescent non-actively growing roots, non-fluorescent actively growing roots and red fluorescent actively growing roots. This could be explained by the fact that the $A$. rhizogenes strain used in this study carries two plasmids, in which the wild type Ri plasmid contains in its TL-DNA the rol genes responsible to induce the phenotype "hairy root", while the binary vector that possesses on its T-DNA 
the gene encoding for the red fluorescent protein, responsible for the phenotype "red fluorescent". In this sense and in order to have the last phenotype of hairy roots mentioned above, a simultaneously occurring double T-DNA transference event was necessary. The other phenotypes are explained by single transference events. On the other hand, line LRT 6.14, which did not amplify the expected fragment corresponding to the rolC gene, can be explained as an incomplete transference event or by rearrangements and deletions that for long time have been known to occur with some frequency during the process of T-DNA transference and integration [15-18].

\subsection{Anti-Inflammatory and Cytotoxic Activity of the Transformed Line LRT 7.31}

The $\mathrm{CH}_{2} \mathrm{Cl}_{2}: \mathrm{CH}_{3} \mathrm{OH}(50: 50 \mathrm{v} / \mathrm{v})$ crude extract obtained from the LRT 7.31 line was tested in the mouse ear edema induced with 12-O-tetradecanoylphorbol-13-acetate (TPA) technique and compared with previous reports as well as with fractioned extracts. Our results showed that the crude extract inhibited by $50.5 \% \pm 6.06 \%$ (mean \pm standard deviation: SD) the inflammation at a dose of $1 \mathrm{mg} / \mathrm{ear}$, with median Inhibitory Concentration $\left(\mathrm{IC}_{50}\right)$ of $1.2 \mathrm{mg} /$ ear. This value was similar with that previously obtained by Salinas et al. from crude extracts of wild plants, in vitro seedlings and callus cultures of this species (58.3\% $\pm 1.73 \%$ of inhibition) [9]. Chromatographic purification of the crude extract afforded four main fractions, of which C1F3 inhibited the TPA-induced inflammation of the mouse ear by $85.6 \% \pm 9.08 \%$ (Mean $\pm \mathrm{SD}$ ) at a dose of $1 \mathrm{mg} /$ ear $\left(\mathrm{IC}_{50} 0.28 \mathrm{mg} /\right.$ ear), higher than the crude extract, and similar than that displayed by the positive control Indomethacin $(85.7 \% \pm 6.47 \%$ : Mean \pm SD) at the same dose.

Regarding to cytotoxicity, the crude extract also showed cytotoxic activity against HCT-15 (colon adenocarcinoma) and OVCAR (ovary carcinoma) with $\mathrm{IC}_{50}$ values of $3.14 \mu \mathrm{g} / \mathrm{mL}$ and $0.57 \mu \mathrm{g} / \mathrm{mL}$ respectively, but non active against HeLa (cervical carcinoma) and KB (laryngeal carcinoma) cancer cell lines (Table 1), whereas the C1F3 fraction showed to be highly active against HeLa and KB cancer cell lines as compared with the crude extract, and still active against HCT-15 and OVCAR. The IC 50 values were $0.00089 \mu \mathrm{g} / \mathrm{mL}, 5.39 \mu \mathrm{g} / \mathrm{mL}, 3.32 \mu \mathrm{g} / \mathrm{mL}$ and $3.069 \mu \mathrm{g} / \mathrm{mL}$, respectively (Table 1).

Table 1. Cytotoxicity $\left(\mathrm{IC}_{50}\right)$ of $\mathrm{CH}_{2} \mathrm{Cl}_{2}: \mathrm{CH}_{3} \mathrm{OH}$ crude extract and fraction $\mathrm{C} 1 \mathrm{~F} 3$ from hairy root line LRT 7.31 and wild plant extract of L. racemosa.

\begin{tabular}{ccccc}
\hline \multirow{2}{*}{ Sample Origin } & \multicolumn{4}{c}{ Cancer Cell Lines } \\
\cline { 2 - 5 } & HeLa $(\mu \mathrm{g} / \mathbf{m L})$ & HCT-15 $(\mu \mathrm{g} / \mathbf{m L})$ & OVCAR $(\mu \mathrm{g} / \mathbf{m L})$ & KB $(\mu \mathrm{g} / \mathbf{m L})$ \\
\hline Crude extract & $63.97 \pm 0.09$ & $3.14 \pm 0.03$ & $0.57 \pm 0.01$ & $>100$ \\
C1F3 & $0.00089 \pm 0.000098$ & $3.32 \pm 0.03$ & $3.069 \pm 0.01$ & $5.39 \pm 0.12$ \\
Wild plants & $>100$ & $5.6 \pm 0.11$ & $0.08 \pm 0.03$ & $>100$ \\
\hline
\end{tabular}

HeLa: Cervical carcinoma; HCT-15: Colon adenocarcinoma; OVCAR: Ovary carcinoma; KB: Laryngeal carcinoma.

Fraction C1F2 did not induce any anti-inflammatory effect and its chemical analysis indicated the presence of the mixture of the triterpenes ursolic (1) and oleanolic (2) acids which were identified by ${ }^{1} \mathrm{H}$ - and ${ }^{13} \mathrm{C}-\mathrm{NMR}$ spectral data [19] as well as by direct comparison with authentic samples available in our laboratory [20]. Although compounds $\mathbf{1}$ and $\mathbf{2}$ have been already described to possess weak anti-inflammatory activity, it is likely that their poor solubility inhibited their detection in our model. Fraction C1F3 was subjected to successive chromatographic purification, obtaining an amorphous solid which probed to be a mixture by NMR and HPLC analyses. The compound 3 present in the crude extract was quantified, being $28.9 \mu \mathrm{g} / \mathrm{mg}$, while in the fraction C1F3 it was $850.0 \mu \mathrm{g} / \mathrm{mg}$. The HPLC profile of fraction C1F3 (Figure 3) indicated that compound 3 is the principal component in the fraction $(85 \%)$ and probably the responsible of the anti-inflammatory and cytotoxic activities displayed by this fraction.

With the aim of identifying this compound, fraction C1F3 was acetylated and further chromatographic purification allowed the isolation of acetylursolic acid (1a) and acetyloleanolic acid (2a) as the minor constituents of the fraction, while the new steroid identified as (23R)-2 $\alpha, 3 \beta, 23,28$-tetraacetyl-14,15dehydrocampesterol (3a) was the major constituent of this fraction (Figure 4). 

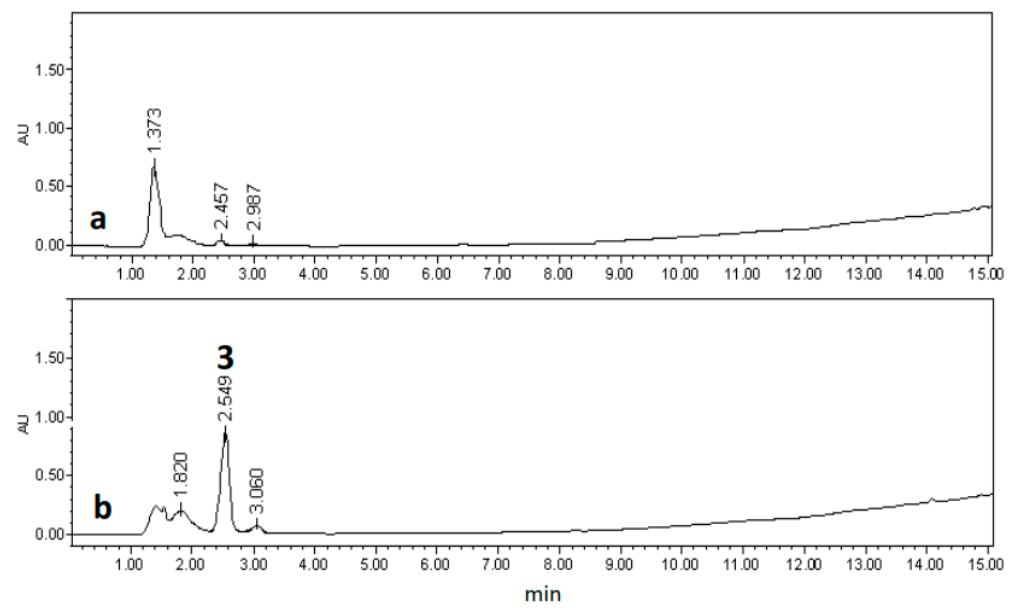

Figure 3. HPLC profiles of (a) $\mathrm{CH}_{2} \mathrm{Cl}_{2}: \mathrm{CH}_{3} \mathrm{OH}$ extract and (b) Fraction $\mathrm{C} 1 \mathrm{~F} 3$ obtained from hairy root line LRT 7.31.

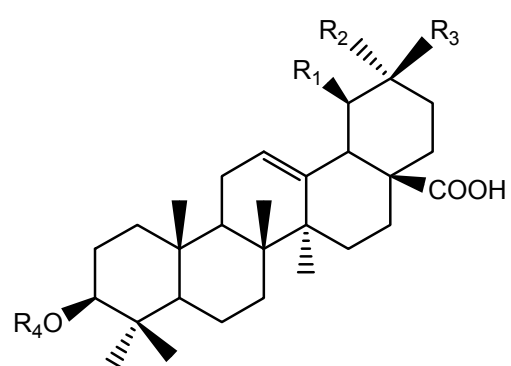

$\begin{array}{llll}\mathbf{R}_{1} & \mathbf{R}_{2} & \mathbf{R}_{3} & \mathbf{R}_{4}\end{array}$

$1 \mathrm{CH}_{3} \mathrm{CH}_{3} \quad \mathrm{H} \quad \mathrm{H}$ 1a $\mathrm{CH}_{3} \mathrm{CH}_{3} \quad \mathrm{H} \quad \mathrm{Ac}$

$\begin{array}{lllll}2 & \mathrm{H} & \mathrm{CH}_{3} & \mathrm{CH}_{3} & \mathrm{H}\end{array}$

2a $\begin{array}{llll}\mathrm{CH}_{3} & \mathrm{CH}_{3} & \mathrm{H} & \mathrm{Ac}\end{array}$

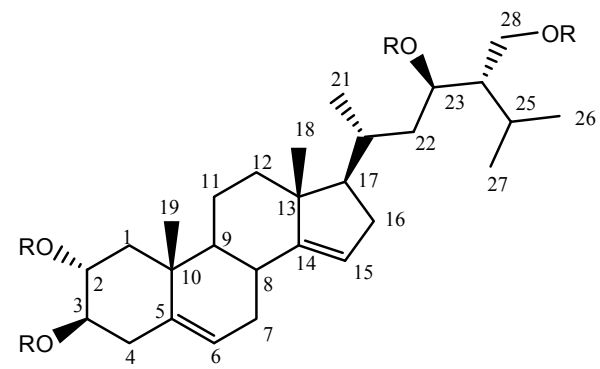

$\mathbf{R}$

$3 \mathrm{H}$

3a Ac

Figure 4. Chemical structure of compounds 1, 1a, 2, 2a, $\mathbf{3}$ and 3a isolated from line LRT 7.31 hairy roots of L. racemosa.

\subsection{Chemical Characterization}

Compound 3a showed a pseudomolecular ion $[\mathrm{M}-\mathrm{H}]^{-}$peak at $m / z 613.3819$ by HRFABMS in the negative mode, corresponding to a molecular formula $\mathrm{C}_{36} \mathrm{H}_{54} \mathrm{O}_{8}$ which was also deduced on the basis of the ${ }^{13} \mathrm{C}-\mathrm{NMR}$ spectrum combined with DEPT data. Assignment of all the ${ }^{13} \mathrm{C}$ - and ${ }^{1} \mathrm{H}-\mathrm{NMR}$ signals for each spin systems is shown in Table 2 . The ${ }^{1} \mathrm{H}$ - and ${ }^{13} \mathrm{C}-\mathrm{NMR}$ data indicate that derivative 3a contains the C-28 tetracyclic steroidal system ring of campesterol $[\delta 1.16(3 \mathrm{H}, \mathrm{s}, \mathrm{H}-18), 1.21(3 \mathrm{H}, \mathrm{s}$, $\mathrm{H}-19), 0.81(3 \mathrm{H}, \mathrm{d}, J=6.4 \mathrm{~Hz}, \mathrm{H}-21), 0.87$ (6H, d, J = 7.6 Hz, H-26, H-27)].

The ${ }^{1} \mathrm{H}-\mathrm{NMR}$ spectrum of compound $3 \mathrm{a}$ displayed signals from the protons of two tetrasubstituted double bonds at $\delta 5.24(1 \mathrm{H}, \mathrm{t}, J=6.8 \mathrm{~Hz})$ and $\delta 5.22(1 \mathrm{H}, \mathrm{t}, J=7.2 \mathrm{~Hz})$, three acetoxy methine groups at $\delta 5.05(2 \mathrm{H}, \mathrm{ddd}, J=3.2,10.4 \mathrm{~Hz})$, and $5.14(1 \mathrm{H}, \mathrm{ddd}, J=4.4,10.4,11.6 \mathrm{~Hz})$, and the AB system of an acetoxy methylene group at $\delta 3.80(1 \mathrm{H}, \mathrm{dd}, J=3.6,11.6)$ and $\delta 3.55(1 \mathrm{H} \mathrm{dd}, J=1.2,12.0 \mathrm{~Hz})$. The ${ }^{13} \mathrm{C}$-NMR spectrum of 3a showed 28 signals $\left(5 \mathrm{CH}_{3}, 8 \mathrm{CH}_{2}, 11 \mathrm{CH}\right.$, and $\left.4 \mathrm{C}\right)$ corresponding to the steroid skeleton, as well as the signals for the four acetates present in the molecule $(\delta 170.72 / 21.53$, $170.54 / 21.02,170.54 / 20.80$ and 170.42/20.77). A detailed analysis of NMR data (COSY, HSQC, and $\mathrm{HMBC}$ ) revealed the absence of the methyl group at C-24 having instead an acetoxy methylene evidenced by the $\mathrm{AB}$ system at $\delta 3.80$ and 3.55, and the observed correlations between the methylene protons at C-28 with C-23 ( $\delta 75.55)$ and C-25 ( $\delta 23.79)$ in the HMBC spectrum (Figure 5), indicating also 
the presence at $\mathrm{C}-23$ of one of the three acetoxy methines deduced early. Comparison of the chemical shift and $J$ values of $\mathrm{H}-23(\delta 5.5, \mathrm{dd} ; J=3.2,10.4 \mathrm{~Hz})$ with those described for related C-23 oxygenated sterols [21] allowed us to establish the C-23R configuration of $3 a$.

Table 2. ${ }^{1} \mathrm{H}(400 \mathrm{MHz})$ and ${ }^{13} \mathrm{C}(100 \mathrm{MHz})$ NMR data for compound 3a (acetone- $\left.d_{6}\right)$.

\begin{tabular}{|c|c|c|c|}
\hline Position & $\delta_{H}$ & $\delta_{C}$ & Type \\
\hline 1 & $1.31,2 \mathrm{H}, \mathrm{m}$ & 39.92 & $\mathrm{CH}_{2}$ \\
\hline 2 & $5.14,1 \mathrm{H}, \mathrm{ddd}(4.4,10.4,11.6)$ & 70.29 & $\mathrm{CH}$ \\
\hline 3 & $5.05,1 \mathrm{H}$, ddd $(3.2,10.4)$ & 75.55 & $\mathrm{CH}$ \\
\hline 4 & $1.76,2 \mathrm{H}, \mathrm{m}$ & 31.43 & $\mathrm{CH}_{2}$ \\
\hline 5 & $-\cdots-1$ & 139.52 & C \\
\hline 6 & $5.24,1 \mathrm{H}, \mathrm{t}(6.8)$ & 122.72 & $\mathrm{CH}$ \\
\hline 7 & $1.74,2 \mathrm{H}, \mathrm{m}$ & 28.83 & $\mathrm{CH}_{2}$ \\
\hline 8 & $1.82,1 \mathrm{H}, \mathrm{m}$ & 38.63 & $\mathrm{CH}$ \\
\hline 9 & $1.68,1 \mathrm{H}, \mathrm{m}$ & 48.45 & $\mathrm{CH}$ \\
\hline 10 & $\ldots$ & 31.38 & C \\
\hline 11 & $1.38,2 \mathrm{H}, \mathrm{m}$ & 23.86 & $\mathrm{CH}_{2}$ \\
\hline 12 & $1.32,2 \mathrm{H}, \mathrm{m}$ & 34.53 & $\mathrm{CH}_{2}$ \\
\hline 13 & $-\ldots-1-$ & 46.84 & $C^{2}$ \\
\hline 14 & - - - - - - & 145.19 & $\mathrm{C}$ \\
\hline 15 & $5.22,1 \mathrm{H}, \mathrm{t}(7.2)$ & 125.89 & $\mathrm{CH}$ \\
\hline 16 & $1.72,2 \mathrm{H}, \mathrm{m}$ & 33.46 & $\mathrm{CH}_{2}$ \\
\hline 17 & $1.72,1 \mathrm{H}, \mathrm{m}$ & 53.96 & $\mathrm{CH}$ \\
\hline 18 & $1.16,3 \mathrm{H}, \mathrm{s}$ & 24.14 & $\mathrm{CH}_{3}$ \\
\hline 19 & $1.21,3 \mathrm{H}, \mathrm{s}$ & 24.24 & $\mathrm{CH}_{3}$ \\
\hline 20 & $1.44,1 \mathrm{H}, \mathrm{c}$ & 33.14 & $\mathrm{CH}$ \\
\hline 21 & $0.81,3 \mathrm{H}, \mathrm{d}(6.4)$ & 17.72 & $\mathrm{CH}_{3}$ \\
\hline 22 & $1.38,2 \mathrm{H}, \mathrm{m}$ & 37.65 & $\mathrm{CH}_{2}$ \\
\hline 23 & $5.05,1 \mathrm{H}, \mathrm{ddd}(3.2,10.4)$ & 75.55 & $\mathrm{CH}$ \\
\hline 24 & $1.24,1 \mathrm{H}, \mathrm{m}$ & 44.41 & $\mathrm{CH}$ \\
\hline 25 & $1.76,1 \mathrm{H}, \mathrm{m}$ & 23.79 & $\mathrm{CH}$ \\
\hline 26 & $0.87,3 \mathrm{H}, \mathrm{d},(7.6)$ & 17.43 & $\mathrm{CH}_{3}$ \\
\hline 27 & $0.87,3 \mathrm{H}, \mathrm{d}(7.6)$ & 17.58 & $\mathrm{CH}_{3}$ \\
\hline 28 & $\begin{array}{c}3.80,1 \mathrm{H}, \mathrm{dd},(3.6,11.6) \\
3.55,1 \mathrm{H}, \mathrm{dd},(1.2,12)\end{array}$ & 65.93 & $\mathrm{CH}_{2}$ \\
\hline $\mathrm{CH}_{3}-\mathrm{CO}-$ & $1.93,3 \mathrm{H}, \mathrm{s}$ & 20.77 & $\mathrm{CH}_{3}$ \\
\hline & $1.93,3 \mathrm{H}, \mathrm{s}$ & 20.80 & $\mathrm{CH}_{3}$ \\
\hline & $1.99,3 \mathrm{H}, \mathrm{s}$ & 21.02 & $\mathrm{CH}_{3}$ \\
\hline & $2.02,3 \mathrm{H}, \mathrm{s}$ & 21.53 & $\mathrm{CH}_{3}$ \\
\hline \multirow[t]{4}{*}{$\mathrm{CH}_{3}-\mathrm{CO}-$} & & 170.42 & C \\
\hline & & 170.54 & $\mathrm{C}$ \\
\hline & & 170.54 & $\mathrm{C}$ \\
\hline & & 170.72 & $\mathrm{C}$ \\
\hline
\end{tabular}

The remaining acetoxymethines at $\delta 5.05$ and 5.14 were located at C-3 and C-2, respectively, by the HMBC correlations between H-2 ( $\delta 5.14)$ with C-1 ( $\delta 39.92)$ and C-10 ( $\delta 31.38)$, and between H-3 ( $\delta 5.05)$ with C-4 ( $\delta 31.43)$ and C-5 ( $\delta$ 139.52). Likewise, HMBC correlations of H-2, H-3, H-23 and H-28 with their corresponding carbonyl esters were observed (Table 2). The $\alpha$-configuration of the C-2 acetoxyl group was evident from the chemical shift and the $J$ values of this proton $(\delta 5.14$, ddd, $J=4.4,10.4,11.6 \mathrm{~Hz}$ ) compared with related compounds $[22,23]$. The ${ }^{1} \mathrm{H}_{-}{ }^{13} \mathrm{C}^{3} \mathrm{~J}$ correlations between the vinylic protons at $\delta 5.24$ with C-8 ( $\delta 38.63)$ and C-10 $(\delta 31.38)$, and between $\delta 5.22$ with C-13 ( $\delta 46.84)$ and C-17 ( $\delta 53.96)$ allowed us to locate the double bonds at C-6 and C-15 respectively (See Supplementary Data). On the basis of all these evidences, the natural product was identified as (23R)-2 $\alpha, 3 \beta, 23,28$-tetrahydroxy-14,15-dehydrocampesterol (3), a new natural product. 


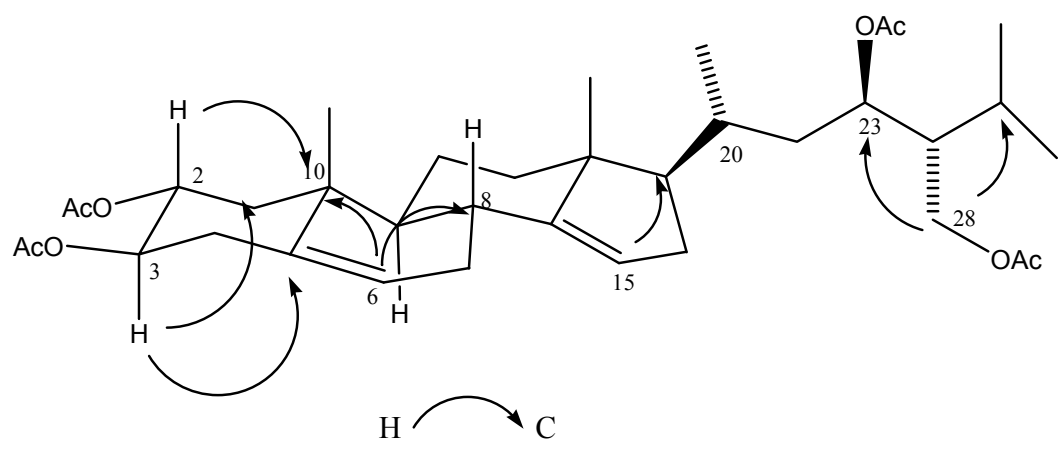

Figure 5. Key HMBC correlations of derivative 3a.

\section{Experimental Section}

\subsection{General Procedures}

Compounds were isolated by means of open column chromatography (CC). Analytical TLC was carried out on precoated silica gel 60F254 plates (Merck, Darmstadt, Germany). All NMR spectra and two-dimensional spectroscopy experiments COSY, HSQC, HMBC were recorded on an INOVA-400 instrument (Varian, Palo Alto, CA, USA) at $400 \mathrm{MHz}$ for ${ }^{1} \mathrm{H}-\mathrm{NMR}$ spectra in $\mathrm{CDCl}_{3}$ with tetramethylsilane (TMS) as internal standard and at $100 \mathrm{MHz}$ for ${ }^{13} \mathrm{C}-\mathrm{NMR}$. Chemical shifts are reported in $\delta$ values. High resolution mass spectrometry in negative ion mode (HRFABMS) was performed using an AX 505 HA (JEOL, Tokyo, Japan) mass spectrometer. The IR spectrum was recorded on a Tensor 27 FTIR (Bruker, Fremont, CA, USA). Melting points were determined on a Fisher-Johns Melting Point apparatus. Optical rotations were measured on a 241 digital polarimeter (PerkinElmer, Waltham, MA, USA) equipped with a sodium lamp (589 nm) and a microcell. High pressure liquid chromatography was performed using a Waters Delta prep 4000 chromatograph equipped with a Waters 717 plus Autosampler and 996 photodiode array detector (Waters Co., Milford, MA, USA), and a Chromolith Performance C18 column $(5 \mu \mathrm{m}, 7.8 \mathrm{~mm} \times 100 \mathrm{~mm})$. The analysis was run with a gradient system of solvent $\mathrm{A}\left(\mathrm{H}_{2} \mathrm{O}: \mathrm{CH}_{3} \mathrm{CN}\right)$ on solvent $\mathrm{B}\left(\mathrm{CH}_{3} \mathrm{CN}\right)$, UV detection at $205 \mathrm{~nm}$ at a flow rate of $1.0 \mathrm{~mL} / \mathrm{min}$, and using $20 \mu \mathrm{L}$ sample injection.

\subsection{Bacterial Strain}

The strain of A. rhizogenes ATCC15834/pTDT [24] was grown over $48 \mathrm{~h}$ at $28 \pm 1{ }^{\circ} \mathrm{C}$ in liquid yeast-mannitol (YM) broth containing spectinomycin $100 \mathrm{mg} / \mathrm{L}$, reaching an optical density (OD) of $0.4-0.6$ at $600 \mathrm{~nm}$.

\subsection{Plant Material}

The seeds of L. racemosa used in the present study were obtained from the stock reported by Salinas et al. [9].

\subsection{Seed Germination and Axenic Seedling Obtaining}

Seeds were surface sterilized in small filter paper bags dipped in a solution of domestic liquid detergent and sterile distilled water $1 \%(v / v)$ for $10 \mathrm{~min}$. followed by $1 \mathrm{~min}$. in $70 \%(v / v)$ ethanol and $15 \mathrm{~min}$ in $15 \%$ commercial bleach ( $6 \%$ active chlorine). Finally, seed bags were rinsed five times in abundant sterile distilled water. Once sterilized, the seeds were transferred to small glass jars containing half strength salts and organic components of Murashige and Skoog [25] (MS) medium, with no plant growth regulators, $3 \%$ sucrose and $0.3 \%$ Gelzan ${ }^{\mathrm{TM}} \mathrm{CM}^{\circledR}$ (Sigma-Aldrich, Co., St. Louis, MO, USA); $\mathrm{pH}$ adjusted to $5.6 \pm 0.1$ and autoclaved at $108 \mathrm{kPa}$ and $121{ }^{\circ} \mathrm{C}$ for $20 \mathrm{~min}$. The glass jars 
were then transferred to a growth chamber and incubated at $25 \pm 1{ }^{\circ} \mathrm{C}$ with a photoperiod of $16 / 8 \mathrm{~h}$ light/darkness and $27 \mu \mathrm{mol} \cdot \mathrm{m}^{2} \cdot \mathrm{s}^{-1}$ white photon flux density.

\subsection{Genetic Transformation}

\subsubsection{Hairy Root Induction}

Leaf explants prepared from 30-day-old aseptic seedlings germinated in vitro were used for infection with the $A$. rhizogenes strain described above. One milliliter of bacterial liquid culture was mixed with $10 \mathrm{~mL}$ of sterile distilled water in a Petri dish. The previously prepared leaf explants were then dipped in this diluted bacterial suspension and incubated for $15 \mathrm{~min}$. The explants were transferred to Petri dishes containing MS/B5 co-culture medium with macro and micro nutrients of the MS medium and vitamins of the Gamborg et al. [26] B5 medium, 3\% sucrose, $0.3 \%$ Gelzan $^{\mathrm{TM}}$ $\mathrm{CM}^{\circledR}$, with no plant growth regulators, $\mathrm{pH}$ adjusted to $5.6 \pm 0.1$ and autoclaved at $108 \mathrm{kPa}$ and $121^{\circ} \mathrm{C}$ for $20 \mathrm{~min}$. A control was established containing non-infected explants. Ten explants per Petri dish containing the co-culture medium were transferred. Co-culture was carried out for $48 \mathrm{~h}$ under the same environmental conditions used during seed germination. The explants were then rinsed three times in sterile distilled water containing $500 \mathrm{mg} / \mathrm{L}$ ticarcillin and $200 \mathrm{mg} / \mathrm{L}$ cefotaxime antibiotics in order to begin the Agrobacterium elimination. The rinsed explants were then placed once again on sterile filter paper and transferred to a fresh co-culture medium containing the same antibiotics (200 mg/L of each) and incubated under the same environmental conditions described above.

\subsubsection{Selection and Establishment of Hairy Root Lines}

Emerged hairy roots from explants infected with Agrobacterium were observed under an epifluorescence microscope (Carl Zeiss V8) and microphotographs were taken. Each hairy root emerged from each explant was removed and individually cultivated in a new Petri dish containing full-strength co-culture MS/B5 medium, with no antibiotics and under the same environmental conditions described above. For selection purposes, each hairy root was classified and identified with the number assigned to its explant and another consecutive number, such that each root could be clearly identified and putatively considered as a root line. Two criteria were used for selection: growth rate and fluorescence. Growth rate was determined for line: LTR-7.31. After six months in culture, these lines produced enough biomass to enable estimation of their GI, and 3 replicates of fresh weight $0.5 \mathrm{~g}$ and a control for initial dry weight were inoculated and cultivated for 30 days in glass jars containing the same culture medium. They were then weighed to determine their fresh weight and dried at room temperature in order to record dry weight. Growth rate was determined as reported by Ashraf et al. [12], calculating the growth index using the following formula: $\mathrm{GI}=\mathrm{rwf}-\mathrm{rwi} / \mathrm{rwi}$; where rwf is final root weight and rwi is initial root weight.

\subsection{DNA Isolation and PCR Analysis}

\subsubsection{DNA Isolation}

Genomic DNA was isolated from fresh plant material of diverse selected hairy root lines and also from non-transformed roots of L. racemosa, using the kit ZR Plant/Seed DNA MicroPrep ${ }^{\mathrm{TM}}$ (Zymo Research, Irvine, CA, USA). A total of $150 \mathrm{mg}$ of each sample were finely cut and placed in a lysis tube, adding $750 \mu \mathrm{L}$ of lysis solution. Each sample was then agitated for $10 \mathrm{~min}$ in a vortex at maximum speed in order to disrupt the tissue. The lysis tube was then centrifuged at $10,000 \times g$ for $1 \mathrm{~min}$. Following centrifugation, $400 \mu \mathrm{L}$ of supernatant was transferred to a filter tube connected to a collector tube and centrifuged once again at $7000 \times g$ for $1 \mathrm{~min}$. All of the following steps were carried out according to the protocol of the kit manufacturer. 


\subsubsection{PCR Analysis}

DNA samples of each hairy root were used as template for PCR analysis to determine the presence of the rolC gene in transformed hairy roots and the absence of virD2 in the same roots using specific primers reported by Bonhomme et al. [27]: 5'TGTGACAAGCAGCGATGAGC3' and $3^{\prime}$ GATTGCAAACTTGCACTCGC $5^{\prime}$ as well as $5^{\prime}$ ATGCCGATCGAGCTCAAGT3 $3^{\prime}$ and $3^{\prime}$ CCTGACC CAAACATCTCGGCTGCCA5 ${ }^{\prime}$. The first pair was designed to amplify a $490 \mathrm{bp}$ fragment of the rolC gene, and the second to amplify a $338 \mathrm{bp}$ fragment of the virD2 gene, which is used as a control since it is not transferred to the plant cell during the transformation process. A DNA amplification kit from Vivantis was used. Each sample was prepared in $500 \mu \mathrm{L}$ PCR tubes on ice in order to obtain a total reaction volume of $50 \mu \mathrm{L}$, comprising $1 \mu \mathrm{L}$ DNA template, $5 \mu \mathrm{L}$ 10X Taq DNA polymerase reaction buffer, $2 \mu \mathrm{L} 50 \mathrm{mM} \mathrm{MgCl} 2,1 \mu \mathrm{L}$ of each primer $(10 \mu \mathrm{M}), 2 \mu \mathrm{L}$ dNTPs mixture $(2 \mathrm{mM}), 0.5 \mu \mathrm{L}$ of recombinant Taq DNA polymerase $(5 \mu / \mu \mathrm{L})$ and $37.5 \mu \mathrm{L}$ of nuclease free water. PCR amplification for both genes was carried out in an Mastercycler Gradient (Eppendorf, Hamburg, Germany) device under the following conditions: 1 cycle of $5 \mathrm{~min}$ at $95^{\circ} \mathrm{C}, 35$ cycles of $1 \mathrm{~min}$ denaturing at $95^{\circ} \mathrm{C}, 1 \mathrm{~min}$ annealing at $50{ }^{\circ} \mathrm{C}$, and $1 \mathrm{~min}$ extension at $72{ }^{\circ} \mathrm{C}$; finally, 1 cycle of $5 \mathrm{~min}$ final extension at $72{ }^{\circ} \mathrm{C}$. The PCR products were subjected to electrophoresis in 1\% agarose gel at 100 volts for $60 \mathrm{~min}$ and visualized on UV transilluminator (BioDoc-It ${ }^{\mathrm{TM}}$ Imaging System, Upland, CA, USA) using ethidium bromide staining and photographed.

\subsection{Extraction and Isolation of Chemicals Compounds from of Selected Hairy Root Line LTR-7.31}

The plant material $(84 \mathrm{~g})$ from the in vitro culture (LTR-7.31) was dried, pulverized and extracted with $\mathrm{CH}_{2} \mathrm{Cl}_{2}: \mathrm{CH}_{3} \mathrm{OH}$ 50:50 ( $\left./ / v\right)$ via maceration at room temperature for $72 \mathrm{~h}(840 \mathrm{~mL} \times 3)$. The liquid extract was filtered using No. 1 Whatman filter paper and concentrated to dry in a Büchi-490 rotary evaporator (Büchi, Flawil, Switzerland) at $40^{\circ} \mathrm{C}$ under low pressure. Final extract (5.7 g) was stored at $4{ }^{\circ} \mathrm{C}$ for later chromatographic and pharmacologic analysis. The extract was fractionated by column chromatography (silica gel 60, Merck) eluting with a gradient system of $n$-hexane:ethyl acetate (100:00 $\rightarrow$ 00:100) to afford four fractions: C1F1, $540 \mathrm{mg}$ (90:10), C1F2, $382 \mathrm{mg}$ (80:20), C1F3, $113 \mathrm{mg}$ (70:30), and C1F4, $422 \mathrm{mg}$ (50:50). Further chromatography of fraction C1F2 over silica gel eluted with $n$-hexane:ethyl acetate $(9: 1)$, gave the natural mixture of the triterpenic acids ursolic (1) and oleanolic (2). C1F3 (60 mg) was acetylated with acetic anhydride (2 mL) and pyridine $(1 \mathrm{~mL})$ for two hours, the product dissolved in dichloromethane was purified by column chromatography with silica gel 60 using a gradient of $n$-hexane:EtOAc (100:00 $\rightarrow$ 70:30) to give $8 \mathrm{mg}$ of the mixture of 3-acetyl ursolic acid (1a) and 3-acetyl oleanolic acid (2a) and $24 \mathrm{mg}$ of the new compound (23R)-2 $\alpha, 3 \beta, 23,28$-tetraacetyl-14,15-dehydrocampesterol (3a). Amorphous solid; $[\alpha]_{D}^{20}+15.4\left(c \quad 0.8 \mathrm{CHCl}_{3}\right) ; \mathrm{IR}(\mathrm{KBr})_{v \max } 2962,1740,1468,832 \mathrm{~cm}^{-1} ;{ }^{1} \mathrm{H}\left(\mathrm{CDCl}_{3}, 400 \mathrm{MHz}\right)$ and ${ }^{13} \mathrm{C}$ $\left(\mathrm{CDCl}_{3}, 100 \mathrm{MHz}\right) \mathrm{NMR}$ data see Table 2; FABMS $m / z 613[\mathrm{M}-\mathrm{H}]^{+}$; HRFABMS (negative) $\mathrm{m} / z$ [613.3819 [M - H] $]^{-}\left(\right.$calcd for $\left.\left.\mathrm{C}_{36} \mathrm{H}_{54} \mathrm{O}_{8}\right)\right]$.

\subsection{Antiinflammatory and Cytotoxic Activities}

\subsubsection{TPA Induced Mice Ear Inflammation Model}

This assay was used to evaluate the anti-inflammatory activity of the plant extracts. Male ICR mice between 25 and $30 \mathrm{~g}$ in weight were maintained under standard laboratory conditions $(12 / 12 \mathrm{~h}$ light/darkness, $25{ }^{\circ} \mathrm{C} \pm 3{ }^{\circ} \mathrm{C}$ temperature, $70 \% \pm 5 \%$ relative humidity, with food and water ad libitum). All procedures were conducted according to the Official Mexican Rule NOM-062-ZOO-1999 (technical specifications for the production, care, and use of laboratory animals) and international ethical guidelines for the care and use of experimental animals. The extracts were dissolved in methanol:acetone 50:50 $\mathrm{v} / \mathrm{v}$ (vehicle) to a final concentration of $50 \mathrm{mg} / \mathrm{mL}$. Mice were divided into 4 groups of 6 mice each; one group was used as negative control (vehicle), another was used to compare the anti-inflammatory drug indomethacin (positive control) with the other groups of tested 
hairy root extracts. To evaluate testing groups, $10 \mu \mathrm{L}$ of each extract was applied to the inner and $10 \mu \mathrm{L}$ to the outer surface of the right ear $(1 \mathrm{mg} / \mathrm{ear})$ of each mouse; the left ear was treated in the same form, but the inner and outer surface were treated with $10 \mu \mathrm{L}$ of vehicle. For the indomethacin (Sigma-Aldrich, Co.) group, $20 \mu \mathrm{L}$ of vehicle was used to apply the compound on the right ear (1 mg/ear) of each mouse and for the 12-O-tetradecanoylphorfol-13-acetate (TPA, Sigma-Aldrich, Co.) control group, only vehicle was used in both ears. After $10 \mathrm{~min}, 2.5 \mu \mathrm{g}$ of TPA was applied to the right ear of all groups in order to induce ear inflammation. Four hours after the application of TPA, the mice were sacrificed in a chloroform chamber followed by cervical dislocation. Finally, circular sections of $6 \mathrm{~mm}$ in diameter were taken from the central part of both the treated (tr) and non-treated (nt) ears of each mouse. Each section was weighed to determine the inflammation percentage by weight difference between the treated and non-treated ear. Percentage of inflammation inhibition was calculated using the following formula: Inhibition $\%=[\Delta \mathrm{w}$ control $-\Delta \mathrm{w}$ extract treated $/ \Delta \mathrm{w}$ control $]$ [100] where $\Delta \mathrm{w}=\mathrm{wtr}-\mathrm{wnt}$; with wtr representing the weight of the section of the treated right ear and wnt the weight of the section of non-treated left ear. A curve of effect-concentration with five different amounts of extract $(0.25,0.5,0.75,1.0$ and $1.5 \mathrm{mg}$ /ear) was generated for the most active extract.

\subsubsection{Cytotoxic Activity}

In order to evaluate the cytotoxic activity of the extracts derived from the hairy root cultures, cell lines of different human cancer types such as: HeLa (Cervical carcinoma), HCT-15 (Colon adenocarcinoma), OVCAR (Ovary carcinoma) and KB (Laryngeal carcinoma) were used. Cell lines were cultivated in Eagle's Minimum Essential Medium (MEM) containing 10\% Fetal Bovine Serum (FBS), under the following conditions: $37^{\circ} \mathrm{C}$ temperature, $5 \%$ atmospheric $\mathrm{CO}_{2}$ and $100 \%$ relative humidity. Cell lines in $\log$ phase were treated with 3 different concentrations of each extract: 1, 10, and $100 \mu \mathrm{g} / \mathrm{mL}$, and incubated for $72 \mathrm{~h}$ under the same environmental conditions. Cell concentration was calculated by protein analysis. Results are expressed as the concentration that inhibits growth by $50 \%$ over the incubation period $\left(\mathrm{IC}_{50}\right)$. Values are estimated from semi-log concentration $(\mu \mathrm{g} / \mathrm{mL})$, versus percentage of viable cells.

\section{Conclusions}

Through a process of genetic transformation and careful selection of hairy roots, we established 22 different lines of actively growing hairy root cultures. From the results of the anti-inflammatory and cytotoxic activities of $\mathrm{CH}_{2} \mathrm{Cl}_{2}: \mathrm{CH}_{3} \mathrm{OH}$ extracts derived from the selected line, we conclude that line 7.31 possesses high anti-inflammatory and cytotoxic activities. In the extract we did not find the compounds which were reported previously by Salinas et al. [11], however, we isolate and characterized a novel compound (23R)-2 $\alpha, 3 \beta, 23,28$-tetrahydroxy-14,15-dehydrocampesterol as the major component in the fraction $\mathrm{C} 1 \mathrm{~F} 3$. It will be necessary to continue with the pharmacological characterization of this major component of the fraction C1F3 in the future. The pharmacological characterization can be done by (a) its further purification, (b) testing its anti-cytotoxic activity in normal human fibroblasts and (c) studying its action mechanism by flux cytometry. Regarding the hairy root line LRT 7.31, it will be necessary to study its growth kinetics and its metabolite production, which can be done by batch culture in liquid medium. Finally, it is important to mention that the present study is the first report about genetic transformation of this plant species.

Supplementary Materials: Supplementary materials can be accessed at: http:/ /www.mdpi.com/1420-3049/22/ $1 / 118 / \mathrm{s} 1$.

Acknowledgments: Centro Investigación en Biotecnología, Universidad Autónoma del Estado De Morelos. Av. Universidad 1001 Col. Chamilpa C.P. 62209, Cuernavaca, Morelos, Mexico. Centro de Investigaciones Químicas-IICBA, Universidad Autónoma del Estado de Morelos, Cuernavaca, Morelos C.P. 62209 Mexico. Centro de Investigación Biomédica del Sur, Instituto Mexicano del Seguro Social. Argentina No. 1 Col. Centro C.P. 62790, Xochitepec, Morelos, Mexico. Consejo Nacional de Ciencia y Tecnología (CONACyT): Fellowship No. 248596 and This research was supported in part by CONACyT (Grant CB 240801). The authors thank Laboratorio Nacional de Estructura de Macromoléculas (Conacyt 251613) for the spectroscopic and 
mass analyses. Alfonso Leija Salas for assistance with the epimicroscopy. Funding: Secretaría de Educación Pública Programa. PROMEP/103.5/13/6626. Consejo Nacional de Ciencia y Tecnología (CONACyT): Fellowship No. 248596.

Author Contributions: Norma Elizabeth Moreno-Anzúrez conducted most of the experiments and data analysis; Laura Álvarez, Irene Perea-Arango, Patricia Castillo-España and Jesús Arellano-García conceived and designed research; Silvia Marquina, Alejandro Zamilpa and Norma Elizabeth Moreno-Anzúrez conducted the phytochemical work; Pilar Nicasio Torres, Maribel Herrera Ruíz and Norma Elizabeth Moreno-Anzúrez conducted the test for anti-inflammatory activity; Jaime Tortoriello García and Edgar Rolando Díaz García conducted the test for cytotoxic activity and Laura Alvarez, Silvia Marquina, Patricia Castillo-España, Irene Perea-Arango and Jesús Arellano-García conducted the data analysis and wrote the article. All authors have read and approved the manuscript.

Conflicts of Interest: The authors declare no conflict of interest.

\section{References}

1. Tian, L. Using Hairy Roots for Production of Valuable Plant Secondary Metabolites. In Filaments in Bioprocesses; Advances in Biochemical Engineering/Biotechnology; Krull, R., Bley, T., Eds.; Springer: New York, NY, USA, 2000; Volume 149, pp. 275-324.

2. Rahnama, H.; Hasanloo, T.; Shams, M.R.; Sepehrifar, R. Silymarin production by hairy root culture of Silybum marianum (L.) Gaertn. Iran. J. Biotechnol. 2008, 3, 113-118.

3. Gunjan, S.K.; Lutz, J.; Bushong, A.; Rogers, D.T.; Littleton, J. Hairy Root Cultures and Plant Regeneration in Solidago nemoralis Transformed with Agrobacterium rhizogenes. Am. J. Plant Sci. 2013, 4, 1675-1678. [CrossRef]

4. Samadi, A.; Jafari, M.; Nejhad, N.M.; Hossenian, F. Podophyllotoxin and 6-methoxy podophyllotoxin production in hairy root cultures of Linum mucronatum ssp. mucronatum. Pharmacogn. Mag. 2014, 10, 154-160. [PubMed]

5. Cequier-Sánchez, E.; Rodríguez, C.; Dorta-Guerra, R.; Ravelo, A.G.; Zárate, R. Echium acanthocarpum hairy root cultures, a suitable system for polyunsaturated fatty acid studies and production. BMC Biotechnol. 2011, 11, 1-14. [CrossRef] [PubMed]

6. Weathers, P.J.; Bunk, G.; McCoy, M.C. The effect of phytohormones on growth and artemisinin production in Artemisia annua hairy roots. In Vitro Cell. Dev. Biol.-Plant 2005, 41, 47-53. [CrossRef]

7. Sharma, P.; Padh, H.; Shrivastava, N. Hairy root cultures: A suitable biological system for studying secondary metabolic pathways in plants. Eng. Life Sci. 2013, 13, 62-75. [CrossRef]

8. Alonso-Castro, A.J.; Villarreal, M.L.; Salazar-Olivo, L.A.; Gomez-Sanchez, M.; Dominguez, F.; García-Carranca, A. Mexican medicinal plants used for cancer treatment: Pharmacological, phytochemical and ethnobotanical studies. J. Ethnopharm. 2011, 133, 945-972. [CrossRef] [PubMed]

9. Cruz-Paredes, C.; Bolívar, B.P.; Gómez-Velasco, A.; Juárez, Z.N.; Sánchez, A.E.; Hernández, L.R.; Bach, H. Antimicrobial, Antiparasitic, Anti-Inflammatory, and Cytotoxic Activities of Lopezia racemosa. Sci. World J. 2013, 2013, 237438. [CrossRef] [PubMed]

10. Salinas, R.; Arellano-García, J.; Perea-Arango, I.; Álvarez, L.; Garduño-Ramírez, M.L.; Marquina, S.; Zamilpa, A.; Castillo-España, P. Production of the Anti-inflammatory Compound 6-O-Palmitoyl-3-O- $\beta$-Dglucopyranosylcampesterol by Callus Cultures of Lopezia racemosa Cav. (Onagraceae). Molecules 2014, 19, 8679-8690. [CrossRef] [PubMed]

11. Rubnov, S.; Kashman, Y.; Rabinowitz, R.; Schlesinger, M.; Mechoulam, R. Suppressors of Cancer Cell Proliferation from Fig (Ficus carica) Resin: Isolation and Structure Elucidation. J. Nat. Prod. 2001, 64, 993-996. [CrossRef] [PubMed]

12. Ashraf, M.F.; Zain, C.R.C.M.; Zainal, Z.; Noor, N.M.; Anuar, N.; Markom, M.; Ismail, I. Establishment of Persicaria minor hairy roots and analysis of secreted $\beta$-caryophyllene in medium broth. Plant Cell Tissue Organ Cult. 2015, 121, 11-20. [CrossRef]

13. Wahyuni, D.K.; Vidianti, F.; Purnobasuki, H.; Ermayanti, T.M.; Prajoga, B.; Utami, E.S.W. Agrobacterium rhizogenes Mediated Hairy Root Induction in Justicia gendarussa Burm.f. J. Appl. Environ. Biol. Sci. 2015, 5, 87-93.

14. Schmulling, T.; Schell, J.; Spena, A. Single genes from Agrobacterium rhizogenes influence plant development. EMBO J. 1988, 7, 2621-2629. [PubMed] 
15. Gheysen, G.; Montagu, M.V.; Zambryski, P. Integration of Agrobacterium tumefaciens transfer DNA (T-DNA) involves rearrangements of target plant DNA sequences. Proc. Natl. Acad. Sci. USA 1987, 84, 6169-6173. [CrossRef] [PubMed]

16. Peerbolte, R.; Ruigrok, P.; Gullems, G.; Schilperoort, R. T-DNA Rearrangements due to tissue culture: Somaclonal variation in crown gall tissues. Plant Mol. Biol. 1987, 9, 51-57. [CrossRef] [PubMed]

17. Meza, T.J.; Stangeland, B.; Mercy, I.S.; Skarn, M.; Nymoen, D.A.; Berg, A.; Butenko, M.A.; Hakelien, A.M.; Camilla Hasleka, C.; Meza-Zepeda, L.A.; et al. Analyses of single-copy Arabidopsis T-DNA-transformed lines show that the presence of vector backbone sequences, short inverted repeats and DNA methylation is not suficient or necessary for the induction of transgene silencing. Nucleic Acids Res. 2002, 30, 4556-4566. [CrossRef] [PubMed]

18. Gelvin, S.B. Agrobacterium-Mediated Plant Transformation: The Biology behind the "Gene-Jockeying" Tool. Microbiol. Mol. Biol. Rev. 2003, 67, 16-37. [CrossRef] [PubMed]

19. Jaki, B.U.; Franzblau, S.G.; Chadwick, L.R. Purity-Activity Relationships of Natural Products: The case of Anti-TB Active Ursolic Acid. J. Nat. Prod. 2008, 71, 1742-1748. [CrossRef] [PubMed]

20. Alvarez, L.; Núñez, M.; Pérez, M.C.; Villarreal, M.L.; Delgado, G. Chemical and Biological Study of Astianthus viminalis. Planta Med. 1994, 60, 98. [CrossRef] [PubMed]

21. Misharin, A.Y.; Mehtiev, A.R.; Morozevich, G.E.; Tkachev, Y.V.; Timofeev, V.P. Synthesis and cytotoxicity evaluation of 22,23-oxygenated stigmastane derivatives. Bioorg. Med. Chem. 2008, 16, 1460-1473. [CrossRef] [PubMed]

22. Yamamoto, S.; Watanabe, B.; Otsuki, J.; Nakagawa, Y.; Akamatsu, M.; Miyagawa, H. Synthesis of 26,27-bisnorcastasterone analogs and analysis of conformation-activity relationship for brassinolide-like activity. Bioorg. Med. Chem. 2006, 14, 1761-1770. [CrossRef] [PubMed]

23. Michelini, F.M.; Ramírez, J.A.; Berra, A.; Galagovsky, L.R.; Alché, L.E. In vitro and in vivo antiherpetic activity of three new synthetic brassinosteroid analogues. Steroids 2004, 69, 713-720. [CrossRef] [PubMed]

24. Bazaldúa, C.; Cardoso-Taketa, A.; Arellano, J.; Camacho-Díaz, B.; Ventura-Zapata, E.; Villarreal, M.L. Podophyllotoxin-like lignans production through hairy roots of Hyptis suaveolens. JCPBS 2014, 4, 37-47.

25. Murashige, T.; Skoog, F. A revised medium for rapid growth and bio-assays with tobacco tissue cultures. Physiol. Plant 1962, 15, 473-497. [CrossRef]

26. Gamborg, O.L.; Miller, R.A.; Ojima, K. Nutrient requirements of suspension cultures of soybean root cells. Exp. Cell. Res. 1968, 50, 151-158. [CrossRef]

27. Bonhomme, V.; Laurain-Mattara, D.; Lacoux, J.; Fliniaux, M.A.; Jacquin-Dubreuil, A. Tropane alkaloid production by hairy roots of Atropa belladonna obtained after transformation with Agrobacterium rhizogenes 15834 and Agrobacterium tumefaciens containing rol A, B, C genes only. J. Biotechnol. 2000, 81, 151-158. [CrossRef]

Sample Availability: Samples of the compounds are not available from the authors.

(C) 2017 by the authors; licensee MDPI, Basel, Switzerland. This article is an open access article distributed under the terms and conditions of the Creative Commons Attribution (CC-BY) license (http://creativecommons.org/licenses/by/4.0/). 